\title{
Whole-Genome Amplification by Single-Cell Comparative Genomic Hybridization PCR (SCOMP)
}

\author{
Nona Arneson, Simon Hughes, Richard Houlston, and Susan Done
}

This protocol was adapted from "PCR-Based Whole Genome Amplification," Chapter 18, in PCR (eds. Hughes and Moody). Scion Publishing Ltd., Oxfordshire, UK, 2007.

\section{INTRODUCTION}

PCR-based whole-genome amplification (WGA) has the goal of generating microgram quantities of genome-representative DNA from picogram or nanogram amounts of starting material. This amplification should introduce little, or ideally no, representational bias. In contrast to other techniques for WGA, PCR-based methods are generally less affected by DNA quality and are more applicable to DNA extracted from various sources (fixed and fresh tissues). Ligation-mediated PCR techniques involve ligating an adaptor sequence onto a "representation" of DNA molecules, generated following enzymatic digestion, random shearing, or chemical cleavage. Single-cell comparative genomic hybridization (SCOMP), described in this protocol, is a form of ligation-mediated PCR that was specifically designed for WGA of extremely limited sources of genomic DNA. The reaction volume is purposely kept to a minimum, and all buffers are optimized to eliminate the need to purify the reaction between steps. In addition, the entire reaction is performed in a single tube. This avoids initial template loss and reduces the risk of PCR contamination. SCOMP begins by converting the genome to a high-complexity representation with a fragment size of $<2 \mathrm{~kb}$ by digesting with the restriction enzyme Msel. This results in a smear in the range of 100-1500 bp. Following enzyme digestion, adaptors containing specific primer sequences (specific to the restriction enzyme used) are ligated onto the ends of the genomic DNA and amplified in a high-stringency PCR. This results in a smear of PCR products in the range of 100-1500 bp, which can be visualized by agarose gel electrophoresis.

\section{RELATED INFORMATION}

When implementing WGA in the laboratory, it is important to assess the entire experimental process closely, including sample collection, fixation, storage, and initial DNA extraction procedures, as all of these factors can affect DNA quality and thus have some bearing on the selection of the WGA technique. When using WGA, it is important first to validate the method selected and to become proficient in the technique before applying it to actual samples. Irrespective of the method selected, it is essential to establish that the results generated from the amplified DNA are indistinguishable from the results obtained from the original genomic DNA.

The DNA that can be amplified by PCR-based WGA includes DNA extracted from fixed, frozen, or archival tissue; whole blood; buccal swabs; single cells; sorted chromosomes; and laser-capture microdissected tissue (for microdissection of tissues embedded in paraffin, the sections must be deparaffinized prior to microdissection). Genomic DNA may be extracted using a variety of commercially available methods such as the QIAmp DNA mini-kit (QIAGEN). Fixation of tissues can introduce sequence variations and reduce overall DNA quality. When studying such tissues, prior examination of the DNA by agarose gel electrophoresis will help determine the DNA quality. The amplified DNA produced is suitable for a range of downstream genetic assays and thus has the potential for use not only in academic research, but also in commercial, forensic, and diagnostic laboratories.

SCOMP was first reported by Klein et al. (1999) for the genetic analysis of single cells. For more 
information about genetic analysis using genomic representation, see Lucito et al. (1998). Protocols for Whole-Genome Amplification by Degenerate Oligonucleotide Primed PCR (DOP-PCR), Whole-Genome Amplification by Improved Primer Extension Preamplification PCR (I-PEP-PCR), Whole-Genome Amplification by Adaptor-Ligation PCR of Randomly Sheared Genomic DNA (PRSG), and GenomePlex Whole-Genome Amplification are also available in this issue of CSH Protocols.

\section{MATERIALS}

CAUTIONS AND RECIPES: Please see Appendices for appropriate handling of materials marked with $\langle!>$, and recipes for reagents marked with $<\mathbf{R}>$.

\section{Reagents}

Agarose (Sigma)

ATP (Roche)

DNA size marker (100-bp ladder; Invitrogen)

dNTP mix (10 mM; $2.5 \mathrm{mM}$ each of dATP, dCTP, dGTP, and dTTP) (Invitrogen)

$<$ ! $>$ Ethidium bromide $(10 \mathrm{mg} / \mathrm{mL}$; Sigma)

Expand Long Template PCR system (3.5 U/ $\mu \mathrm{L} ;$ Roche)

This includes Expand Long Template Buffer 1 and Expand Long Template Polymerase. Other PCR systems designed for high-fidelity PCR may be used in this protocol but have not been tested.

Genomic DNA (5 ng/ $\mu \mathrm{L}$ )

If purified genomic DNA is used, the concentration can be in the range of $10-100 \mathrm{ng} / \mathrm{mL}$.

$\mathrm{H}_{2} \mathrm{O}$ (nuclease-free; Promega)

Msel (20 U/ $\mu \mathrm{L}$; New England Biolabs)

Oligonucleotides:

ddMse11 (5'-TAACTGACAGCdd-3') $(100 \mu \mathrm{M})$

LIB1 (5'-AGTGGGATTCCTGCTGTCAGT-3') $(100 \mu \mathrm{M})$

One-Phor-All Buffer Plus (GE Healthcare)

Orange loading dye (6X; Fermentas)

QIAquick PCR purification kit (QIAGEN)

T4 DNA ligase (5 U/ $\mu \mathrm{L}$; Roche)

$<\mathrm{R}>$ TBE buffer ( $1 \mathrm{X}$ diluted from a $10 \mathrm{X}$ stock at $\mathrm{pH} 8$; may also be obtained from Sigma)

\section{Equipment}

Electrophoresis apparatus

Heating block or water bath preset to $37^{\circ} \mathrm{C}$ and $65^{\circ} \mathrm{C}$

Microcentrifuge

Pipettes for mixing solutions

Spectrophotometer

Thermal cycler

Ultracentrifuge

\section{METHOD}

Prepare at least two individual WGA amplifications for each DNA to be studied.

\section{Restriction Enzyme Digestion of Template Genomic DNA}

If several SCOMP reactions are going to be generated for subsequent analysis (i.e., more than 2-3 $\mu$ g is required), perform a larger volume digestion (Step 1), and aliquot it prior to Step 5.

1. Combine the following reagents: 


$\begin{array}{ll}0.2 \mu \mathrm{L} & \text { One-Phor-All Buffer Plus } \\ 0.2 \mu \mathrm{L} & \text { Msel } \\ 3 \mu \mathrm{L} & \text { DNA template }\end{array}$

Add nuclease-free $\mathrm{H}_{2} \mathrm{O}$ to a final reaction volume of $5 \mu \mathrm{L}$.

The $3 \mu \mathrm{L}$ of template can be added directly after proteinase $K$ inactivation without any purification. This is useful if the DNA has been laser-capture microdissected or when the entire amount of template is expected to be extremely limited (<100 $\mathrm{ng}$ ).

A negative control using $3 \mu \mathrm{L}$ of purified $\mathrm{H}_{2} \mathrm{O}$ should also be used to monitor for contamination. If desired, a positive control using $10 \mathrm{ng}$ of good-quality genomic DNA may also be used to monitor successful PCR. See Troubleshooting.

2. Mix well by pipetting up and down, and incubate for $3 \mathrm{~h}$ at $37^{\circ} \mathrm{C}$.

3. Inactivate the Msel by incubating the reaction for $5 \mathrm{~min}$ at $65^{\circ} \mathrm{C}$.

4. Consolidate the reaction mixture by centrifuging at $12,000 \mathrm{~g}$ for $10-20 \mathrm{sec}$.

\section{SCOMP Adaptor Ligation}

5. Prepare adaptor complexes by combining the following reagents:
$0.5 \mu \mathrm{L}$
One-Phor-All Buffer Plus
$0.5 \mu \mathrm{L}$
LIB1 oligonucleotide
$0.5 \mu \mathrm{L}$
ddMse11 oligonucleotide
Add nuclease-free $\mathrm{H}_{2} \mathrm{O}$ to a final reaction volume of $3 \mu \mathrm{L}$.
Prepare an adaptor for each sample from Step 4, including the negative control.

6. To form the adaptor complexes, incubate the sample using a step-down program on a thermal cycler going from $65^{\circ} \mathrm{C}$ to $15^{\circ} \mathrm{C}$, ramping at $1^{\circ} \mathrm{C} / \mathrm{min}$.

7. Leaving the samples at $15^{\circ} \mathrm{C}$, add to each reaction:
$1 \mu \mathrm{L}$
ATP
$1 \mu \mathrm{L}$
T4 DNA ligase

8. Add the total volume $(5 \mu \mathrm{L}$ ) of the Msel-digested genomic DNA (from Step 4), and mix well by pipetting up and down.

9. Incubate overnight $(\sim 12-16 \mathrm{~h})$ at $15^{\circ} \mathrm{C}$.

10. Centrifuge the reactions in a microcentrifuge to collect the droplets formed by evaporation.

\section{SCOMP PCR Amplification}

11. Prepare a PCR master mix with the following reagents for each reaction from Step 10, including the negative control:
$4 \mu \mathrm{L}$
$2 \mu \mathrm{L}$
Expand Long Template Buffer 1
$1 \mu \mathrm{L}$
dNTP mix
Add nuclease-free $\mathrm{H}_{2} \mathrm{O}$ to a final reaction volume of $40 \mu \mathrm{L}$.

12. Add $40 \mu \mathrm{L}$ of the PCR master mix to the ligated genomic DNA fragments from Step 10 and place in a thermal cycler with the following three-stage combined program:

i. Stage 1: Initial incubation for $3 \mathrm{~min}$ at $68^{\circ} \mathrm{C}$, followed by 15 cycles of denaturation for 40 $\mathrm{sec}$ at $94^{\circ} \mathrm{C}$, annealing for $30 \mathrm{sec}$ at $57^{\circ} \mathrm{C}$, and elongation for $1 \mathrm{~min}, 30 \mathrm{sec}$ at $68^{\circ} \mathrm{C}$ with an increment of $1 \mathrm{sec} / \mathrm{cycle}$.

The initial incubation at $68^{\circ} \mathrm{C}$ (Stage 1) is required to fill in the recessive $3^{\prime}$-end of the lower DNA strand to generate a complementary primer sequence.

ii. Stage 2: Eight cycles of denaturation for $40 \mathrm{sec}$ at $94^{\circ} \mathrm{C}$, annealing for $30 \mathrm{sec}$ at $57^{\circ} \mathrm{C}$ with an increment of $1^{\circ} \mathrm{C} / \mathrm{cycle}$, and elongation for $1 \mathrm{~min}, 45 \mathrm{sec}$ at $68^{\circ} \mathrm{C}$ with an increment of $1 \mathrm{sec} / \mathrm{cycle}$. 
iii. Stage 3: 22 cycles of denaturation for $40 \mathrm{sec}$ at $94^{\circ} \mathrm{C}$, annealing for $30 \mathrm{sec}$ at $65^{\circ} \mathrm{C}$, and elongation for $1 \mathrm{~min}, 30 \mathrm{sec}$ at $68^{\circ} \mathrm{C}$ with an increment of $1 \mathrm{sec} / \mathrm{cycle}$, followed by a final extension for $3 \mathrm{~min}, 40 \mathrm{sec}$ at $68^{\circ} \mathrm{C}$.

The thermal cycler program was provided by Dr. C. Klein (Klein et al. 1999). Further optimization of these cycling parameters has not been tested.

Assessment, Cleaning, and Quantification of PCR Products

13. Determine the size of the products from Step 12 as follows:

i. Mix $5 \mu \mathrm{L}$ of the reaction mix with $1 \mu \mathrm{L}$ of $6 \mathrm{X}$ orange loading dye solution.

ii. Resolve the aliquot by Agarose Gel Electrophoresis on a 1\% agarose gel containing $20 \mu \mathrm{g}$ of ethidium bromide $(10 \mathrm{mg} / \mathrm{mL})$ per $100 \mathrm{~mL}$ of agarose, beside a DNA size marker.

Ideally, fragments generated from a good-quality genomic DNA sample should range from 100 to 1500 bp. The more degraded the original genomic DNA sample, the smaller the PCR fragments will be. The negative-control lane should be free of any product formation.

See Troubleshooting.

14. Clean each sample using the QIAquick PCR purification kit according to the manufacturer's instructions, but elute the PCR products in $50 \mu \mathrm{L}$ of $\mathrm{H}_{2} \mathrm{O}$.

If higher concentrations are required for downstream applications, the elution volume can be decreased from 50 to $30 \mu \mathrm{L}$, as recommended by QIAGEN.

15. Quantify the products using spectrophotometry. See Troubleshooting.

\section{TROUBLESHOOTING}

Problem: There is amplification in the negative control.

[Step 13.ii]

Solution: Due to the manipulation of PCR products in all PCR-based WGA methods, the reactions can easily be contaminated. If negative controls produce a DNA smear, several steps can be tried to eliminate this:

- Repeat using fresh reagents.

- Use filtered tips to avoid introduction of contaminants via aerosol from the pipette.

- Physically separate the areas in the laboratory where reactions are set up. Prepare and pipette the PCR mixture at one bench, and then add the DNA to the reaction in a different location in the laboratory. Also, use different pipettes for reaction preparation and pipetting of DNA.

- Aliquot all reaction constituents; if an aliquot becomes contaminated, only that aliquot will be lost and not the entire stock.

Problem: Unpredictable amplification is observed.

[Step 13.ii]

Solution: A positive control (such as starting with $50 \mathrm{ng}$ of good-quality genomic DNA) can be used to ensure that the reaction is working optimally. In addition:

- Store small aliquots of dNTPs and oligonucleotides, because repeated freeze/thaw cycles of a single stock can affect the integrity of these reagents and thereby affect the efficiency of WGA.

- The starting concentration of DNA is crucial. Best results are obtained when starting with 10 ng (or more) of DNA extracted from fresh tissue/blood or $100 \mathrm{ng}$ of DNA extracted from fixed tissue. Lower amounts of DNA ( $<10 \mathrm{ng}$ from fresh tissue or $<100 \mathrm{ng}$ from fixed tissue) will generate amplification products, but results obtained in downstream applications may not be faithful to the result that would have been obtained from nonamplified DNA.

- In ligation-mediated PCR techniques, lack of amplification or poor amplification may be due to problems with either the DNA or the adaptor ligation. For the former, always include a positive control of 10-100 ng of good-quality, high-molecular-weight DNA. If this sample produces good 
results, the assay problems are a product of the DNA sample under investigation. However, if the positive control does not amplify, it suggests a problem with the reaction constituents or the thermal cycling. In such cases, use fresh aliquots of reagents, and repeat the experiment. If the problem still persists, it may be necessary to order fresh reagents.

Problem: The amplification smear contains smaller DNA fragments than expected.

[Step 13.ii]

Solution: The efficiency of amplification is dependent on the quality of the starting DNA, and the size of the amplification products is also template-dependent. Tissue fixation causes degradation of template DNA within the sample. If the template is degraded, as is DNA from formalin-fixed, paraffin-embedded material, the smear will be smaller in size. Unfortunately, there is no way of improving this; thus care must be taken when using such products for downstream applications, because there may be more bias in these samples. Although PCR-based WGA is tolerant to mild or moderate DNA degradation and will amplify DNA with an average length of $\sim 200 \mathrm{bp}$, in this case it is essential to use increased quantities of starting DNA $(100 \mathrm{ng})$ to guarantee a satisfactory yield of final product. Moderate to severe degradation will reduce WGA efficiency and subsequently decrease the quality of results obtained in downstream applications.

Problem: There is insufficient DNA for downstream reactions.

[Step 15]

Solution: Combining at least two individual WGA amplifications for each DNA to be studied is recommended, as this has produced better results in downstream experiments.

Problem: Unpredictable results are obtained from downstream applications.

Solution: Successful PCR-based WGA and successful downstream results depend on the quality of starting DNA. For instance, if there is ineffective PCR amplification of a specific control gene with nonamplified DNA, negative results after WGA are to be expected. If using laser-capture microdissected material, a standard control PCR and a PCR using DNA from non-laser-capture microdissected tissue should be performed prior to WGA. In some cases, it may be necessary to try different amounts of amplified DNA in downstream PCR amplification procedures, for example, 12, 25, 50, and $100 \mathrm{ng}$.

\section{DISCUSSION}

The PCR products resulting from SCOMP have been used for several downstream applications, including chromosomal comparative genomic hybridization (CGH) (Klein et al. 1999), array CGH (Ghazani et al. 2006), loss of heterozygosity (Klein et al. 1999) analysis, and direct sequencing (Klein et al. 1999). Both chromosomal CGH and array CGH analysis require the SCOMP products to be labeled in an additional reaction with appropriate dyes. When using SCOMP products for a comparative analysis (test and control), it is essential to treat both the DNA of interest and the control genomic DNA in the same manner. Because SCOMP reduces the genome to only a representation, it is important that control DNA is also a representation and that the control DNA be of similar quality to the DNA of interest. For example, if the DNA of interest was extracted from formalin-fixed, paraffin-embedded material, then the control "normal" DNA should also be from this source and preferably from the same patient. Pooling several replicate SCOMP reactions from the same sample may also help to reduce any bias that may be introduced in the PCR amplification step.

\section{REFERENCES}

Ghazani, A.A., Arneson, N.C., Warren, K., and Done, S.J. 2006. Limited tissue fixation times and whole genome amplification do not impact array CGH profiles. J. Clin. Pathol. 59: 311315.

Klein, C.A., Schmidt-Kittler, O., Schardt, J.A., Pantel, K., Speicher, M.R., and Riethmüller, G. 1999. Comparative genomic hybridiza- tion, loss of heterozygosity, and DNA sequence analysis of single cells. Proc. Natl. Acad. Sci. 96: 4494-4499.

Lucito, R., Nakimura, M., West, J.A., Han, Y., Chin, K., Jensen, K., McCombie, R., Gray, J.W., and Wigler, M. 1998. Genetic analysis using genomic representations. Proc. Natl. Acad. Sci. 95: 44874492. 


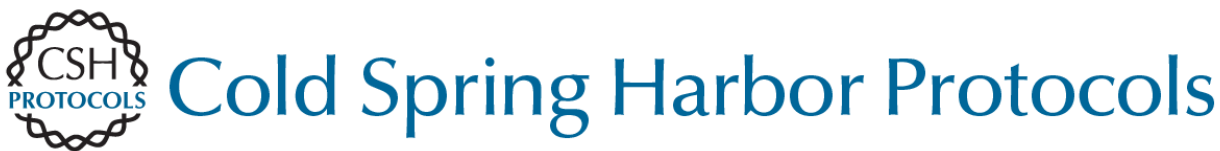

\section{Whole-Genome Amplification by Single-Cell Comparative Genomic Hybridization PCR (SCOMP)}

Nona Arneson, Simon Hughes, Richard Houlston and Susan Done

Cold Spring Harb Protoc; doi: 10.1101/pdb.prot4923

\begin{tabular}{cc}
\hline $\begin{array}{r}\text { Email Alerting } \\
\text { Service }\end{array}$ & Receive free email alerts when new articles cite this article - click here. \\
\hline $\begin{array}{c}\text { Subject } \\
\text { Categories }\end{array}$ & Browse articles on similar topics from Cold Spring Harbor Protocols. \\
& Amplification of DNA by PCR (85 articles) \\
& Bioinformatics/Genomics, general (192 articles) \\
& DNA Sequencing (96 articles) \\
& Genetic Variation (86 articles) \\
& Genetics, general (374 articles) \\
& Genome Analysis (191 articles) \\
& Genomic DNA (135 articles) \\
& Genomic Libraries (66 articles) \\
& Libraries (147 articles) \\
& Libraries, general (113 articles) \\
& Molecular Biology, general (1293 articles) \\
& Polymerase Chain Reaction (PCR) (139 articles) \\
& Polymerase Chain Reaction (PCR), general (184 articles) \\
& \\
&
\end{tabular}

